Yet all users of a library know that changes are necessary. If a scholar knows, through consultation, what the problems of the librarian are, he will accept those changes more willingly than if he is left in ignorance of the inner workings of the librarian's mind. The simplification arising in cataloging from cost, all will accept, and any other changes which the common interest of librarians and scholars may dictate. .

Any person who knows a library from the standpoint of independent research will know how complex the management of great stores of printed material is and likewise he will appreciate the effectiveness of the staffs of university libraries. Whatever changes must be made, should be made in light of the observed needs of the users of libraries and in the light of the experience of the professional librarian. It must be, in the nature of the case, a slow process but one that is constant. The scholar and the librarian both have a profound common interest in the preservation and expansion of the American library. The elements of professional jealousy and scholarly arrogance must fade in the common consciousness of the larger issues before us in the maintenance of the library, scholarly or otherwise, as a functioning element in our democratic way of life.

\title{
In Anticipation of Reconstruction
}

\begin{abstract}
$\hat{C}^{\mathrm{M}}$
MERICAN LIBRARIANS in research institutions, harassed during the last several months with missing issues and volumes of foreign journals, can sympathize with their European and Asiatic colleagues. Those librarians have for the last few years had the multiple problem of delivery failures, extensive reductions in budgets, necessitating almost wholesale journal cancellations, and in many instances destruction of important sets already held by the institutions. The size of this complex problem is impossible to estimate at the present time but we have sufficient evidence already to know that it is of huge proportions. And with no immediately cheerful prospects of change in the international situation we can assume that the problems for both foreign and American institutions will continue to multiply.
\end{abstract}

Whether we in the United States receive aid in completing our sets of foreign journals or not there is considerable satisfaction to be derived from knowing that work has been accomplished in this country which will aid in the future rehabilitation of foreign institutions. The Rockefeller Foundation, with its constant interest in international scholarship, has given to the American Library Association grants totaling $\$ I_{1} 10,000$ to be used to purchase current issues of important American journals to be shipped to European and Asiatic research institutions at the end of hostilities. The Committee on Aid to $\mathrm{Li}$ braries in War Areas has been responsible for the administration of this program. A brief report on the acquisition of this supply appeared in the April 1942 issue of the A.L.A. Bulletin.

(Continued on page 268) 


\section{In Anticipation of Reconstruction}

\section{(Continued from page 206)}

By the end of 1942 the Association will own a supply of I 939-42 issues of many of the most important research journals. The committee assumes that the supply will be adequate to cope with the requests from at least the outstanding foreign research centers and that European and Asiatic scholarship therefore will not be entirely deprived of the product of American research during the war years.

\section{Augmenting Purchased Supply}

The committee would like to be able to accomplish more than this and has realized from the first the necessity for augmenting the purchased supply of journals with an active campaign for gifts. The lack of large-scale storage space has made the postponement of such a campaign seem wise. In the meantime the committee is doing everything it can to insure the success of this future campaign.

The supply of learned journals is never large and even under normal conditions tends to disappear rapidly. With today's abnormal demand for material for pulp this supply will be rapidly absorbed unless definite steps are taken to protect it. The December issue of this journal carried, as did other library periodicals, a brief statement of the aims of the committee in the preservation of scholarly journals. Many of the journals themselves are currently printing a similar statement in an attempt to notify individual scholars. These statements have brought forth offers and promises of gifts and have undoubtedly prevented some destruction of the supply. The committee feels that the institutions and individuals represented in the Association of College and Reference Libraries are the logical source of further assistance.

Though a large-scale campaign isn't yet possible small campaigns can be accomplished and will contribute greatly to the success of the final program. At least in one instance a local campaign is already in progress. Flora B. Ludington, the librarian of Mount Holyoke College, has reported such a campaign and its success should encourage librarians of other institutions. A brief statement of the problem in faculty meeting, supported by personal appeals to individual faculty members, will bring offers and promises of current journals. A letter to the emeritus members of the teaching staff will make available another supply. The library duplicate collection can be combed with the committee's interest in mind, setting aside odd numbers or complete volumes of the important American journals.

The committee will be grateful for any activity of this nature, sure that it is attracting and protecting a quantity of important research material that would no longer be available for collection in even a year or two. A list of some four hundred journals, judged to be those for which the committee will receive the most requests, has been prepared. Requests for this list, questions concerning the project, and reports of cooperative activity should be directed to Wayne M. Hartwell, Executive Assistant to the Committee on Aid to Libraries in War Areas, Rush Rhees Library, University of Rochester, Rochester, N.Y. 